УДК 636.223.083.314

(C) 2018

Колісник О. І., кандидат сільськогосподарських наук

директор ПП «Агро - Новоселівка 2009» Харківської області

\author{
Прудніков В. Г., доктор сільськогосподарських наук, професор, \\ Криворучко Ю. І., кандидат сільськогосподарських наук \\ Харківська державна зооветеринарна академія
}

Нагорний С. А., кандидат сільськогосподарських наук

Харківський національний технічний університет сільського господарства ім. Петра Василенка

\title{
ХАРАКТЕРИСТИКА ОРГАНІЗАЦЙНО-ТЕХНОЛОГІЧНИХ УМОВ ПРИ УТРИМАННІ М'ЯСНИХ КОРІВ АБЕРДИН-АНГУСЬКОЇ ПОРОДИ В СТІЙЛОВИЙ ПЕРІОД БЕЗ ВИКОРИСТАННЯ ПРИМІЩЕНЬ
}

\section{Рецензент - доктор сільськогосподарських наук, професор А. М. Хохлов}

У статті розглянуто питання щзодо характеристики організаційно-технологічних умов при утриманні корів та нетелей абердин-ангуської породи в стійловий період на відкритих відгодівельних майданчиках без використання примімень в умовах Східного регіону Украӥни. В статті розраховано технологічну карту утримання корів та нетелей: об'єм роботи, машини та обладнання, яке використовується при обслуговуванні тварин, витрати праці, кількість обслуговуючого персоналу. Наведено розрахунки найбільи працемістких елементів технології.

Ключові слова: м'ясне скотарство, технологія, технологічні карти, корови абердинангуської породи, рух поголів'я, стійловий періod.

Постановка проблеми. Ефективність роботи господарств із розведення м'ясної худоби залежить від технології, яка застосовується. А їі вибір, у свою чергу, обумовлюється природнокліматичними умовами, забезпеченістю кормами, матеріальними, трудовими ресурсами, наявністю пасовищ.

Перевага надається такому типу технології, яка для кожного конкретного господарства найбільш доцільна і значною мірою відповідає біологічним потребам тварин. Метою використання даної технології є отримання високої продуктивності тварин при мінімальних витратах праці. Тому основним завданням господарств, які вирощують м'ясну худобу, є максимальне зменшення витрат на утримання худоби, а не отримання максимальних приростів живої маси 3 невиправданими витратами корму.

Економічну ефективність м'ясного скотарства зумовлюють біологічні особливості м'ясної худоби, спеціальні технології, організація годівлі тварин, управління стадом.
Його розвиток можливий без значних витрат коштів на капітальне будівництво приміщень для утримання худоби та дорогу техніку з обслуговування, не потребує висококваліфікованих фахівців для обслуговування тварин.

Істотна перевага м'ясного скотарства полягає в застосуванні маловитратної ресурсозаощадної технології, використання якої, в поєднанні з умілим управлінням стадом, дозволяє економічно ефективно виробляти яловичину [2].

Аналіз основних досліджень і публікацій, у яких започатковано розв'язання проблеми. В умовах сьогодення більшість господарств 3 виробництва яловичини при управлінні технологією не в повній мірі застосовують технологічні карти, в яких прорахована необхідна кількість машин, механізмів при роздаванні та згодовуванні кормів, кількість обслуговуючого персоналу та ін. Це позбавляє можливості прорахувати витратну та прибуткову частину технології [1].

Завдання дослідження - розробка технологічних карт 3 виробництва яловичини при застосуванні маловитратної ресурсозаощадної технологіï м'ясного скотарства та наукове іï обгрунтування 3 характеристикою енерго- та ресурсовитратності технологічних процесів.

Матеріали та методика досліджень. Дослідження та подальші розрахунки проводили в ПП «Агро - Новоселівка 2009» Нововодолажського району Харківської області, де вирощується м'ясна худоба абердин-ангуської породи за ресурсозаощадною маловитратною технологією м'ясного скотарства, особливістю якої $є$ утримання всіх статево-вікових груп тварин цілорічно без приміщень із максимальним використанням пасовищ у весняно-осінній період та утриманням в стійловий період в реконструйованих силосних сховищах і на відкритих майданчиках. 


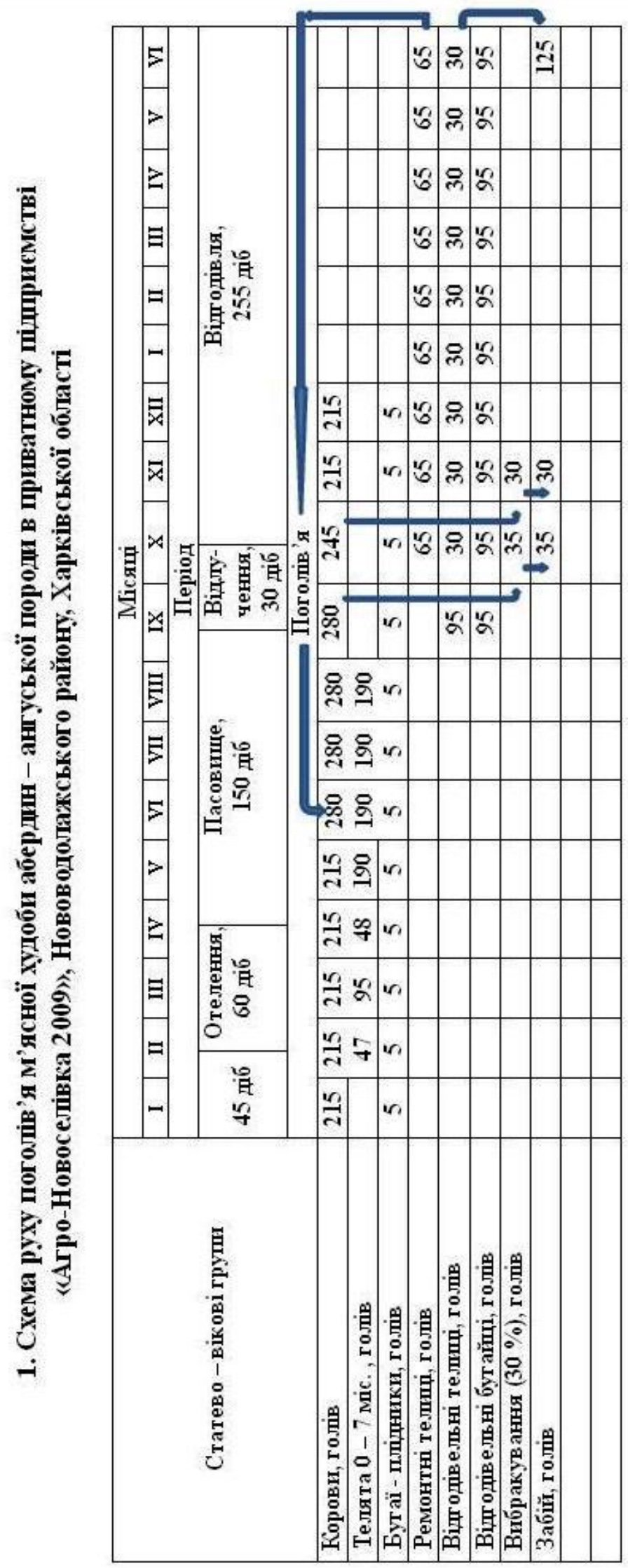




\begin{tabular}{|c|c|c|c|c|c|c|c|c|c|c|c|c|c|c|c|c|}
\hline \multirow{3}{*}{ 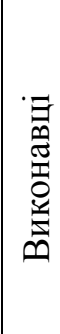 } & 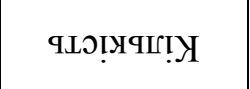 & $\stackrel{n}{0}$ & $\overrightarrow{\sigma_{0}}$ & $\begin{array}{l}n \\
0 \\
0 \\
0\end{array}$ & $\stackrel{\infty}{\stackrel{\infty}{=}}$ & & 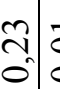 & \begin{tabular}{l|l}
$\overrightarrow{0}$ & 7 \\
0 & 0
\end{tabular} & \begin{tabular}{l|l} 
& 0 \\
0 \\
0
\end{tabular} & $\frac{7}{0}$ & $\overbrace{0}^{0}$ & $\tilde{O}_{0}$ & $\begin{array}{l}0 \\
0 \\
0\end{array}$ & $\frac{m}{0}$ & $\frac{n}{0}$ & N \\
\hline & 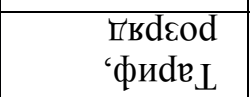 & $\geq$ & $\geq$ & $\geq$ & $\geq$ & & & $>>$ & $>>$ & $>$ & $>$ & $>$ & $>$ & $>$ & $\Xi$ & \\
\hline & 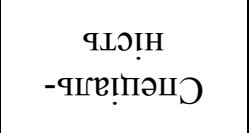 & ثे & 今ે & 咅 & 今े & & 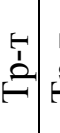 & ڤn & 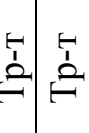 & $\mid \begin{array}{l}1 \\
\vdots \\
\vdots \\
n\end{array}$ & $\stackrel{1}{\stackrel{1}{6}}$ & $\stackrel{\hat{c}}{\hat{n}}$ & 点 & 它 & 莣 & \\
\hline $\bar{\Xi}$ & 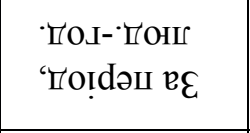 & $\stackrel{\Delta}{\stackrel{\Delta}{N}}$ & $\tilde{\hat{\sigma}}$ & in & $\begin{array}{l}n \\
n \\
\infty \\
0 \\
N\end{array}$ & & 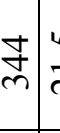 & $\stackrel{\sim}{\sim} \delta$ & 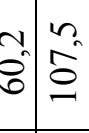 & $\left|\begin{array}{l}\infty \\
0 \\
0 \\
0 \\
1\end{array}\right|$ & $\stackrel{n}{n}$ & $\frac{n}{n}$ & $\begin{array}{l}n \\
\hat{0} \\
-\end{array}$ & बे & $\overrightarrow{0}$ & 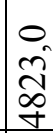 \\
\hline 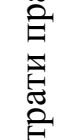 & 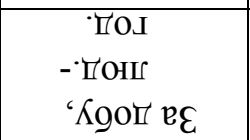 & $\begin{array}{l}0 \\
\text { n. } \\
0\end{array}$ & ते & $\begin{array}{l}0 \\
2 \\
0 \\
0\end{array}$ & $\hat{\imath}$ & & $\stackrel{0}{-}=$ & $\overrightarrow{0}$ & \begin{tabular}{c|c}
$\infty$ & $n$ \\
& $n$ \\
0 & 0
\end{tabular} & $\stackrel{2}{\dddot{2}}$ & $\underset{n}{n}$ & $\underset{n}{n}$ & $\tilde{n}$ & $\hat{\sigma}$ & 今. & \\
\hline$\stackrel{\vec{n}}{\varphi}$ & $\begin{array}{l}\text { гол/'gx 'Кэен } \\
\text { gицеwdoH }\end{array}$ & $\overrightarrow{0}$ & $\begin{array}{l}\bar{\infty} \\
0\end{array}$ & $\overrightarrow{0}$ & $\underset{\substack{q \\
m}}{\stackrel{g}{m}}$ & & $\begin{array}{lll}0 & 1 \\
0 & 1 & \\
0 & & 0\end{array}$ & 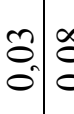 & \begin{tabular}{l|l}
$\infty$ & \pm \\
0 & 0 \\
0 & 0
\end{tabular} & $\begin{array}{l}n \\
2 \\
0\end{array}$ & $\hat{0}$ & '. & 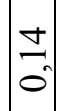 & $\begin{array}{l}\text { ָू } \\
\text { ָू } \\
0\end{array}$ & $\hat{0}$ & \\
\hline & $\begin{array}{c}\text { ниптек } \\
\text { qьэ!мqц!ฺ }\end{array}$ & ' & ' & ' & ' & & ' & ' & ' & ' & ' & ' & I & ' & 1 & ' \\
\hline 焉 & $\begin{array}{c}\text { ГоО } \\
\text { 'инипвк иц } \\
-\operatorname{ogod} \cdot \text { gud }_{L}\end{array}$ & ' & ' & ' & ' & & ڤ. & 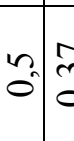 & \begin{tabular}{c|c}
$\tilde{3}$ & $\cdots$ \\
0 & 0
\end{tabular} & $\begin{array}{l}n \\
n \\
m\end{array}$ & $\underset{i}{\text { f }}$ & $\frac{n}{m}$ & $\hat{\sigma}$ & $\stackrel{n}{\approx}$ & I & \\
\hline 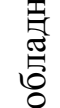 & $\begin{array}{c}\text { п/'gх 'иниптек } \\
\text { 'тодШ }\end{array}$ & ' & ' & ' & ' & & $\underset{\substack{\mathfrak{N} \\
\sim}}{=}$ & 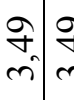 & 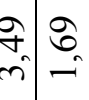 & $\approx$ & $\begin{array}{l}n \\
n \\
0\end{array}$ & $\begin{array}{l}n \\
n \\
0\end{array}$ & $\mid$ & 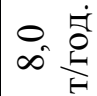 & & , \\
\hline 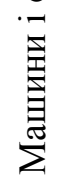 & енипеј & ' & ' & ' & 1 & & 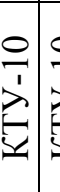 & 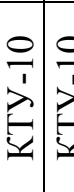 & 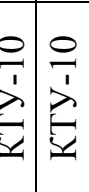 & 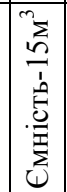 & 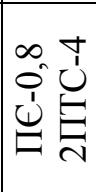 & 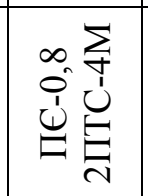 & $\mid \begin{array}{c}0 \\
0 \\
1 \\
\\
2 \\
2\end{array}$ & 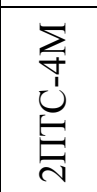 & & 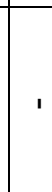 \\
\hline & $\begin{array}{c}\text { ияоэвє } \\
\text {-олдән日 }\end{array}$ & ' & ' & ' & & . & $\sum_{\substack{1 \\
1}}^{2}$ & 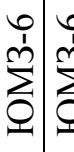 & 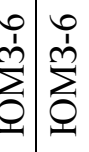 & \begin{tabular}{l|}
0 \\
0 \\
\\
0 \\
0
\end{tabular} & $\sum_{0}^{0}$ & $\sum_{0}^{0}$ & $\mid \begin{array}{l}0 \\
\sum_{1}^{1} \\
0 \\
0\end{array}$ & $\sum_{0}^{0}$ & & \\
\hline $\mathbb{E}$ & ஈо!̣dəш & ' & ' & I & & 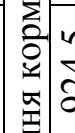 & 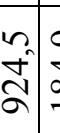 & 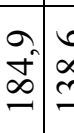 & \begin{tabular}{l|l}
$b$ & $\sigma_{0}$ \\
$\infty$ & $n$ \\
$n$ & $=$
\end{tabular} & ה̊ & 8 & $\begin{array}{l}n \\
\text { ñ }\end{array}$ & $\left|\begin{array}{l}\infty \\
- \\
\delta \\
8 \\
\infty\end{array}\right|$ & $\hat{8}^{\infty}$ & & ' \\
\hline $\begin{array}{l}0 \\
\vdots \\
\vdots \\
\Sigma\end{array}$ & Kgo & $\frac{n}{\sim}$ & $\frac{n}{n}$ & $\frac{n}{2}$ & $\frac{n}{\sim}$ & 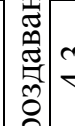 & $\stackrel{m}{*}$ & 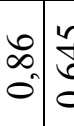 & \begin{tabular}{l|l}
0 & 0 \\
0 & $n$ \\
0 & 0 \\
0 & 0
\end{tabular} & $\because$ & $\hat{\hat{o}}$ & $\cong$ & $\begin{array}{l}2 \\
\hat{2}\end{array}$ & ڤे & $\frac{n}{2}$ & $\frac{n}{2}$ \\
\hline 0 & $\begin{array}{c}\text { Кд!ฺкия } \\
\text { !пиниґо }\end{array}$ & Sं & த் & த் & த் & 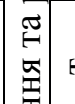 & $H$ & $H$ & $H$ & $H$ & $H$ & $H$ & $H$ & $H$ & 5 & ' \\
\hline & 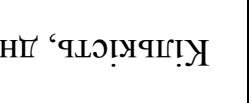 & $\frac{n}{\sim}$ & $\frac{n}{\sim}$ & $r$ & $\frac{n}{\sim}$ & & $\frac{n}{2}$ & $\stackrel{\sim}{\sim} \frac{r}{\sigma}$ & $\frac{n}{\sim} \frac{n}{\sim}$ & $\stackrel{0}{\sim}$ & - & $\frac{n}{n}$ & - & - & $\frac{n}{2}$ & $\frac{n}{n}$ \\
\hline & 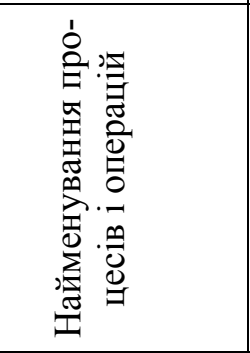 & 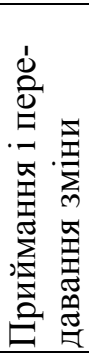 & 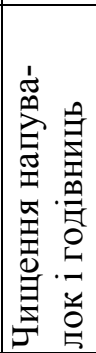 & 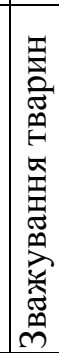 & 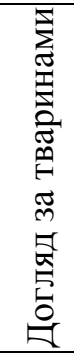 & 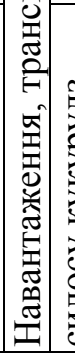 & 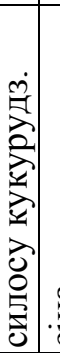 & $\cdot \frac{\widetilde{g}}{\tilde{J}}$ & 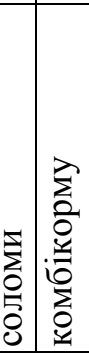 & 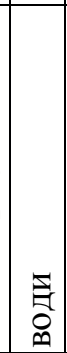 & 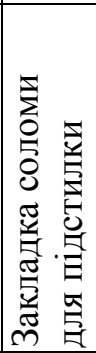 & 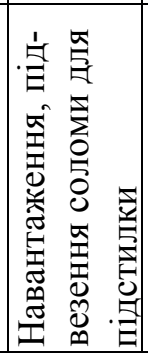 & 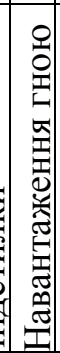 & 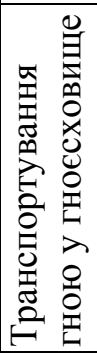 & 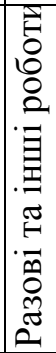 & 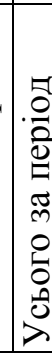 \\
\hline & 竞 $\frac{F}{m}$ & - & $N$ & $m$ & 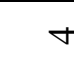 & & & $n$ & & & 6 & $r$ & $\infty$ & $a$ & 0 & 二 \\
\hline
\end{tabular}


- Приймання та передача зміни

$\square$ Чищення напувалок і годівниць

Зважування тварин

$\square$ Догляд за тваринами

$\square$ Навантаження, транспортування

та роздавання силосу

- Навантаження, транспортування та роздавання сіна

- Навантаження, транспортування та роздавання соломи

- Навантаження, транспортування

та роздавання концкормів

$\square$ Транспортування та розлив

води

- Закладка соломи для підстилки

- Навантаження, підвезення

соломи для підстилки

- Навантаження гною

$\square$ Транспортування гною на поля

$\square$ Разові та інші роботи

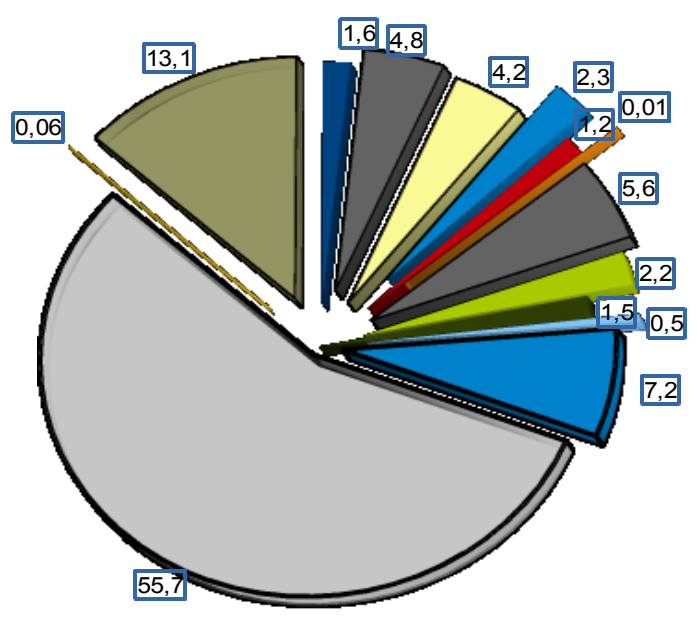

\section{Рисунок 1. Витрати праці (людино-годин) за стійловий період, \%}

Результати дослідження. При застосуванні енергозберігаючої технології виробництва яловичини в умовах м'ясного скотарства виникає необхідність у досконалих розрахунках організаційно-технологічних умов виконання робіт при утриманні тварин різних статево-вікових груп для подальшого економічного обгрунтування запропонованої технології. При утриманні корів і нетелей абердин-ангуської породи стійловий період триває 215 днів (табл. 1).

Спосіб утримання - безприв'язний на довгонезмінній солом'яній підстилці (табл. 2). Кратність роздавання підстилки - щоденно, з першочерговим iii внесенням шаром товщиною 30 см восени в кількості 60 тонн. Щоденна кількість підстилки залежить від змін умов навколишнього середовища. В сприятливих умовах при сонячній або морозній погоді без опадів добова кількість на тварину становить 3 кг. Якщо випадають опади у вигляді дощу чи мокрого снігу, з прохолодними вітрами - кількість соломи збільшують до 7 кг на голову. Для навантаження, транспортування та роздачі корму, підстилки, води, видалення гною потрібен лише один працівник.

Напування корів та нетелів - дворазове. Воду підвозять трактором ЮМЗ-6 в цистерні ємністю 15 м3, яку добувають із артезіанської свердловини i підвозять через 30-45 хвилин після роздавання силосу та концентрованих кормів. Напувалки на відгодівельних майданчиках не мають електропідігріву і в морозні дні при замерзанні води оператори

\section{БІБЛІОГРАФІЯ}

1. Технологічні карти з виробництва продукції тваринництва / За ред. Д. І. Мазоренка, О. А. Науменка, Є. 3. Петруші, І. Г. Бойка. - Харків: ХНТУСГ, 2007. - С. 64-91.

2. Угнівенко А.М., Петренко С.М., Носе- зачищають їх від льоду, що збільшує витрати праці. При падінні температури нижче $-20^{\circ} \mathrm{C}$ силос в раціоні корів заміняють на сінаж і збільшують добову норму концентратів та сіна. Видалення гною 3 відгодівельних майданчиків відбувається один раз на рік бульдозером після переведення корів на пасовища. В періоди, коли атмосферні опади випадають у значній кількості, гній з водою накопичується біля годівниць і цю масу вивозять на поля у якості органічних добрив.

Для зважування та догляду за тваринами, чищення напувалок, годівниць у стійловий період, виходячи 3 наших розрахунків, необхідно лише два оператори, які повністю виконують вище зазначену роботу. При оцінці загальних витрат праці (рис. 1) було встановлено, що найбільший відсоток витрат людино-годин припадає саме на догляд за тваринами $-55,7 \%$. Також значні витрати праці в стійловий період при утриманні корів і нетелей складають чищення годівниць і напувалок - 13,1 \%, навантаження, транспортування та роздавання силосу $7,2 \%$, напування худоби водою - 5,6\%. Загальні витрати за 215 днів стійлового періоду складають 4823 людино-годин. Загальна кількість працюючих при обслуговуванні корів і нетелів - 3 людини.

Висновки. Аналіз розрахунків організаційнотехнологічних умов утримання м'ясної худоби в стійловий період без використання приміщень свідчить про доцільність використання і впровадження маловитратної енергозаощадної технології в умовах Східного регіону України.

вич Д. К., Токар Ю. І. Наукові основи розвитку м'ясного скотарства в Україні / А.М. Угнівенко, С.М. Петренко, Д.К. Носевич, Ю.І. Токар // Монографія. - К. : Компринт, 2016. -330 с. 